\title{
Criatividade em movimento
}

\author{
Creativity in movement
}

\section{Creatividad en movimiento}

r ou estar. Mover-se ou ficar. As dualidades da vida nos encontram muitas vezes despreparados para rompermos a inércia e desafiarmos o que está consolidado, criando movimento. A roda da cultura, por seu tempo, não espera por nada ou ninguém. Em tempos de inovação na velocidade do pensamento, o ser humano é instado a ser criativo além do que talvez imaginasse ser.

Se a nossa ideia de mundo gira a uma velocidade de 365 dias por ano, o pensamento acadêmico e o setor corporativo atropelam essa configuração. E, se isso era até certo ponto confortável, acabamos por ser lançados a desafios gerados por novos modelos econômicos; por safras geracionais (e não nos referimos a idades ou anos de nascimento, mas a mudanças que ocorrem todo o tempo e por diversos fatores mobilizadores) ansiosas com a falta de noção do que seja tempo; por organizações, empresas e instituições que buscam a resposta para consolidar espaços e relacionamentos.

A criatividade, elemento essencial do ser humano, passa a estar presente em novos significados, em associações que tinham mais 0 peso da razão e agora cedem lugar e atenção à construção de novas vias, formatadas (ou desformatadas) com o pensamento da economia criativa. Se o mundo está em crise permanente-de valores, de recursos -, esse novo cenário pode permitir que se estenda a novas frentes a alternativa da busca do equilíbrio. 0 que está consolidado está em cheque e por esse motivo a equipe editorial de Organicom chegou ao tema da economia criativa, já presente em diversas pesquisas acadêmicas, representado em ações e interesses organizacionais e que oferece massa crítica para a reflexão sobre um interessante campo de estudos e de prática, unindo pensamento e ação.

O conjunto de textos que compõem o dossiê sobre "Comunicação e economia criativa" oferece uma leitura bastante atualizada de como 
academia e mercado enxergam o dia a dia e as perspectivas para esse campo. Este número 23 da revista apresenta sete artigos na seção do dossiê propriamente dito, além de uma série de textos em outras seções.

Abre o dossiê o texto "Escola sem fronteiras: educação superior para a sociedade digital", no qual Maria Carolina Garcia apresenta o desafio enfrentado pelas instituições universitárias na "elaboração de ofertas educacionais específicas para o campo das mídias sociais digitais, entendidas como vetor de desenvolvimento da economia criativa". Karina Poli Lima da Cunha e Mitsuru H. Yanaze, no artigo "Economia criativa, um paradigma de política pública contemporâneo? Uma discussão conceitual", com base em estudos desenvolvidos na Inglaterra e na observação da incorporação da economia criativa em políticas públicas daquele país, buscam entender "como o conceito de economia criativa está incorporado aos programas, projetos e ações de políticas públicas de diferentes países influenciados pelos discursos de agências multilaterais, tais como a Unesco e a Unctad". Bárbara Martins Zaganellie Marcelo Carlos Gantos, em "Economia laranja e comunicação: uma nova partilha do valor da informação na era da criatividade", discutem "o processo de (re)arranjo no cenário da comunicação e os atuais desafios da mídia pensando em uma nova forma de partilha da informação pelo viés da economia laranja, isto é, pela economia da cultura e criatividade". Elisangela Machado Mortari, no artigo "A ocupação do espaço público para a resolução de conflitos: construindo cidades criativas", procura mostrar como "a sinergia das organizações na ocupação do lugar público permitirá que os conflitos sejam conduzidos ao status de produção de afetos, gerando bem-estar social, cultural e econômico para os cidadãos".

Ainda na seção do dossiê, Roberto Gondo Macedo e Alessandra de Castilho, com o texto "Economia criativa e comunicação governamental: Movimento 90 e a remodelagem visual da cidade de São Paulo", descrevem como "a economia criativa ganha força no debate de revitalização de grandes cidades e espaços que necessitam de soluções para amenizar problemas de ordem urbana, tendo a comunicação como aliada na conscientização de um novo comportamento". Sergio Nestriuk, em "Indie gamescomo paradigma da indústria criativa: perspectivas e possibilidades comunicacionais", mostra como "os games representam o embrião e o solo primevo da cultura digital e por isso mesmo podem ser entendidos como o paradigma da economia criativa dentro da cultura contemporânea, oferecendo novas e interessantes perspectivas comunicacionais para uma geração de nativos digitais". Por fim, o sétimo texto dessa seção, "Relações públicas e economia criativa: aproximações entre a atuação profissional e as demandas do mercado cultural", de Flavi Ferreira Lisboa Filho, Rogério Saldanha Corrêa e Carine de Almeida Vieira, reflete sobre "a economia criativa a partir do mercado da cultura e as oportunidades para 0 relações-públicas na área cultural".

A seção de Ensaios, que entra nesta edição, enriquece a temática do dossiê com mais três substanciosos textos, relacionados com o cerne das pesquisas às quais se dedicam seus autores. Karin Vecchiatti, em "Criatividade, diversificação e aprendizado nas economias locais", defende a ideia de que "as profissões criativas apresentam a possibilidade de contribuir para 0 desenvolvimento de uma localidade, uma vez que, em grande medida, apresentam flexibilidade e agilidade na diversificação econômica e apoiam seu desenvolvimento no aprendizado". Gilson Schwartz, renomado pesquisador ligado a essa temática, no texto "Cidade do conhecimento e os jogos da iconomia com moedas criativas", traz a visão da iconomia, que ele vem explorando e aprofundando há mais anos, na teoria e na prática; ele discorre também sobre políticas de desenvolvimento humano com oportunidades em larga escala associadas à economia criativa e audiovisual, que se torna "elemento crítico para a superação da crise contemporânea, num contexto de violência geopolítica". Guilherme Fráguas Nobre, em seu ensaio "A economia criativa e o valor potencial da Escola de Comunicações e Artes", trabalhando os conceitos de economia criativa e economia imaterial, além de qualificar os setores da economia criativa, apresenta a atual relação da ECA-USP com a economia criativa, sugerindo, ainda, caminhos possíveis e potencialmente promissores. 
0 destaque, no contexto do dossiê sobre comunicação e economia criativa, é a entrevista que Organicom fez com 0 especialista norte-americano Steven Pedigo. Ele falou ao coordenador do dossiê, Sidney Ferreira Leite, pró-reitor e docente do Centro Universitário Belas Artes, de São Paulo, sobre a base das pesquisas que desenvolve no Creative Class Group e na Universidade de Nova York, onde dirige o departamento de Creative Cities \& Civic Innovation. Além de discorrer, de forma ampla, sobre os conceitos de economia e de classe criativa, o professor apresentou uma lista de iniciativas referenciais, algumas das quais potencialmente úteis para se fazer benchmark no Brasil.

Ainda quanto à temática do dossiê, mencione-se, da seção de resenhas, a que Dario de Barros Vedana, com o título de "A formação de designers no contexto da economia criativa", fez do livro Communication design: insights from the creative industries, pontuando o impacto do design de comunicação na economia criativa. A obra, publicada em Londres pela Bloomsbury (2015), é de Derek Yates e Jessie Price.

Não se ligam especificamente à temática do dossiê os quatro artigos da seção inicial, Espaço Aberto. Trata-se de trabalhos originados das teses e dissertações que se colocaram nos três primeiros lugares no 2ํㅜ Prêmio Abrapcorp de Teses e Dissertações, conferido no IX Congresso Brasileiro Científico de Comunicação Organizacional e Relações Públicas, realizado em 2015 na cidade de Campinas (SP). Assim, se oferecem aos leitores o artigo "A gestão da comunicação no processo de racionalização do trabalho: os ditames de relações públicas no Brasil e na França (anos 1930-1960)", de Claudia Nociolini Rebechi; "Elementos comunicacionais da estratégia das organizações", de Victor Márcio Laus Reis Gomes; "Desafios comunicacionais na gestão estratégica pelo balanced scorecarde o choque de gestão no estado de Minas Gerais", de Fábia Pereira Lima; e, fechando a seção, "A interlocução entre poder público e cidadãos na proposta de gestão compartilhada da prefeitura de Belo Horizonte" de Laura Nayara Pimenta.

Na seção de Resenhas, aparecem ainda outras duas, mais ligadas com obras atuais sobre a comunicação organizacional. Bárbara Miano, em "Comunicação que transforma a realidade", discorre sobre a obra Nueva teoria estratégica: el paradigma emergente para la co-construción y transformación de la realidad, de Raúl Herrera Echenique e Rafael Alberto Pérez, publicada pelo Editorial Santillana e pelo Foro Iberoamericano sobre Estrategias de Comunicación (Santiago do Chile, 2014). E Luciene Patricia C. de Godoy, em "Ascensão do resto", aborda o livro O mundo pós-americano, de Farid Zakaria, traduzido pela Cia. das Letras (2008).

Ao longo de já mais de dez anos, Organicom tem trazido ao cenário da comunicação organizacional e das relações públicas a proposta de discutir temas presentes no dia a dia e também trazer temas inovadores. Este - a comunicação e a economia criativa - pode ser entendido como um produto do dia a dia, cada vez mais demandado, mais requerido, mas ao mesmo tempo ainda não tão conhecido. A urgência quanto ao alargamento nas discussões dessa temática é decorrente de um cenário em que o que está estabelecido já não basta, já não se basta. Organicom cumpre seu papel de também manter um fio condutor entre academia e mercado, valorizando as iniciativas e priorizando o pensamento inclusivo, a ideia do debate como parte essencial da ciência, sempre com base na tolerância e no respeito. E que após a leitura, muito se debata, em nome da ciência! 